\title{
O DISCURSO DE CAMPANHA DE ANTONIO BELINATI: elementos para uma análise sociológica*
}

\author{
Carina Paccola
}

Jornalista; Especialista em Sociologia e Sociologia da Educação.

Este trabalho analisa o discurso de campanha de Antonio Belinati, nas quatro vezes em que concorreu à Prefeitura de Londrina. O objetivo é identificar os recursos de linguagem que o político utiliza, na tentativa de manter uma relação de proximidade com os eleitores. O discurso de campanha foi analisado a partir de matérias e editoriais do jornal Folha de Londrina e de autores que trabalham a comunicação e a linguagem, e a prática do populismo no Brasil. É possível detectar que Belinati tem uma prática política personalista. A imagem de "candidato do povo" consolidou-se ao longo dos seus trinta anos de carreira política. De origem humilde, Belinati estabelece uma relação de afetividade com os eleitores mais pobres.

Palavras-chave: personalismo; campanha eleitoral; discurso político; povo; pobreza; conciliação; despolitização.

\section{INTRODUÇÃO}

$\mathbf{O}$ objetivo deste trabalho é analisar o discurso político do atual prefeito de Londrina, Antonio Belinati (PFL), durante as campanhas eleitorais para a prefeitura do município, e identificar na fala do político os recursos de convencimento e a tentativa de se aproximar do público eleitor. Belinati exerce o mandato de prefeito pela terceira vez em Londrina.

Elegeu-se para o cargo pela primeira vez em 1976, pelo MDB, com uma votação consagradora. Em 1988, foi eleito prefeito pela segunda vez, agora no PDT, com uma vitória apertada sobre José Tavares (PMDB). Radialista de profissão, Antonio Belinati iniciou sua carreira política no $\mathrm{MDB}$, em 1968, quando foi o vereador mais votado de Londrina. Com 2.507 votos, ficou pouco abaixo do candidato a prefeito menos votado, Arvid Ericcsson, da Arena, que recebeu 2.824 .

Em 1970, elegeu-se deputado estadual, também com o maior número de votos. Em 1972, concorreu pela primeira vez à prefeitura e perdeu para José Richa. Em 1974, conquistou uma cadeira na Câmara Federal, sendo o quarto parla- mentar mais votado do país. Voltou à Assembléia Legislativa em 1983. Entrou para o PDT em 1985 e, em 1994, foi eleito para o terceiro mandato como deputado estadual.

Para o atual mandato, venceu as eleições de 1996, no segundo turno, contra o deputado federal Luiz Carlos Hauly (PSDB). Durante a campanha de 1998 para as eleições de governadores, presidente, deputados e senadores, Belinati desincompatibilizou-se do PDT para poder apoiar a candidatura do governador Jaime Lerner (PFL) à reeleição. Sua esposa Emilia Belinati também reelegeu-se vice-governadora do estado. Belinati ficou sem partido por alguns meses e, em 1999, filiou-se ao PFL.

Antonio Belinati nasceu em Campo Grande (MS), em 25 de outubro de 1943, filho de José Belinati e de Helena Casemiro Belinati. Chegou em Londrina com 5 anos de idade. Aos 8, começou a trabalhar como balconista, passando depois à profissão de radialista.

A constituição do fenômeno Belinati ganha corpo com sua chegada à prefeitura, em 1976. A Folha de Londrina, na edição de 17 de novembro de 1976, anunciava a vitória de Antonio Belinati nas eleições daquele ano. O título da matéria de capa da Folha é "O fenômeno Belinati chega à Prefeitura". Conforme o texto, Belinati, "filho de ferroviário e de

\footnotetext{
* O texto é uma adaptação da monografia de mesmo nome apresentada como trabalho de conclusão do curso de Especialização em Sociologia e Sociologia da Educação, da UEL, em abril de 1999, sob orientação da professora Maria José de Rezende.
}

Rev. Mediações, Londrina, v. 4, n. 2, p. 19-31, jul./dez. 1999 
origem humilde, venceu todas as barreiras naturais de uma cidade constituída, em sua maior parte, de classe média e alta, e chega à Prefeitura de Londrina obtendo a expressiva consagração de 36.356 votos, superando sozinho os três candidatos da Arena". (O FENÔMENO..., 1976, p.1)

A escolha do discurso de campanha de Antonio Belinati como objeto de estudo ocorreu por ter despertado na autora o interesse em tentar compreender como um político, que usa uma linguagem eminentemente popular, que se diz representante dos pobres, pode ainda, em pleno final de século, convencer os eleitores de que realmente vai resolver os problemas das camadas menos favorecidas. Ao estudar o discurso de Belinati, o trabalho pretende contribuir para desmistificar a figura de um político que constrói a imagem de um benfeitor para a sociedade. $O$ trabalho quer desmascarar o que está por trás da suposta intimidade entre eleitores e candidatos, para mostrar que o discurso personalista tem caráter desmobilizador da sociedade.

Londrina é um município de porte médio, localiza-se no sul do país, é dotada de universidades conceituadas e, no entanto, elege há trinta anos um político personalista. O que há de tão atraente nesse discurso político? Outros políticos também têm se mantido no poder há anos na cidade, mas nenhum com o carisma de Belinati. Enquanto muitos candidatos se notabilizam por seus conhecimentos técnicos ou por possuir características de empreendedor, Belinati não tem curso superior nem se esforça em parecer refinado - apesar de possuir muitos bens. Seu único trunfo é ser o "candidato do povo". Isso não significa que seja contra os ricos. Ele é um conciliador: jamais se permite um embate político franco e direto.

O trabalho também pretende avaliar se esse discurso personalista desmobiliza a sociedade. Afinal, com um prefeito tão popular, tão acessível para as camadas mais pobres - ele costuma abrir a porta do gabinete para atender a população - , quem precisa se organizar para conquistar algum benefício social?

Para analisar o discurso de Belinati, foi escolhido o material de campanha das quatro eleições para prefeito das quais ele participou $(1972,1976,1988$ e 1996). Esse material foi publicado pelo jornal Folha de Londrina, único periódico da cidade que cobriu todas as quatro campanhas eleitorais.

O trabalho utilizou-se ainda de uma entrevista feita em fevereiro de 1999 pela autora com o atual prefeito Antonio Belinati, com o objetivo de avaliar qual a consciência do político a respeito do seu poder de influência sobre a população.

A análise da prática política de Antonio Belinati encontra respaldo nas teorias que explicam a crise de representação que vivem o Brasil e outros países. Em "O debate contemporâneo sobre a representação política", Marcos Novaro fala da desarticulação dos movimentos populares e do fortalecimento dos líderes carismáticos, que se "auto-apresentam" como representantes diante da sociedade.

Em "Clientelismo e política no Brasil: revisitando velhos problemas", George Avelino Filho critica a legislação eleitoral brasileira, que reforça o individualismo na ação parlamentar e o consequiente enfraquecimento das relações dos parlamentares com os partidos a que pertencem. “(...) a campanha eleitoral se dá primordialmente entre candidatos e não entre partidos. Isso reforça a concepção, vigente entre os políticos, que tende a considerar a cadeira parlamentar como propriedade individual". (AVELINO FILHO, 1994, p.232)

\section{O CANDIDATO DO POVO}

Como radialista, Antonio Belinati mantinha um diálogo direto com a população, o que facilitou a divulgação de seu nome como candidato, em 1968, a vereador. Mas o fato de trabalhar num meio de comunicação não assegura vitória a qualquer profissional que se candidate a cargo eletivo. No livro Comunicação e indústria cultural, Gabriel Cohn reúne vários estudos sobre a comunicação. No capítulo 3 , intitulado "A comunicação humana", Franklin Fearing cita George Mead que diz que a comunicação entre seres humanos só ocorre quando ambas as partes estão envolvidas. Mead chama isso de "assumir a atitude do outro". (MEAD apud FEARING, 1975, p.58)

Para Mead, na base de todas as relações humanas está a percepção de que a outra pessoa é dotada de certas razões, crenças, atitudes ou interesses. Segundo o autor, um sempre tenta aferir as peculiaridades potenciais de outro mesmo numa comunicação rápida e casual. Ao longo do trabalho, com a apresentação das falas do candidato, ficará claro que Belinati aprimorou sua percepção pessoal para levar em conta sempre o que se passa na mente do outro, principalmente quando o outro faz parte da camada mais pobre da população.

Na primeira campanha para prefeito, em 1972, a Folha de Londrina publicou matéria com as declarações do então deputado estadual Belinati aos maçons. Naquele ano, os maçons convidaram os quatro candidatos (José Richa, Antonio Belinati, Álvaro Dias e Mário Stamm) para discutir suas propostas.

$\mathrm{Na}$ apresentação aos maçons, o candidato Belinati explicou que a sua candidatura foi quase uma imposição popular. "O meu partido decidiu aceitar o lançamento do meu nome para concorrer à Prefeitura de Londrina depois que recebeu inúmeros memoriais do povo pedindo a nossa candidatura". Em outro trecho, o candidato diz: "A nossa candidatura, portanto, é uma homenagem ao povo de Londrina". (AS DECLARAÇÕES..., 1972, p.3)

Como proposta, ele afirma que pretende "humanizar Londrina". E exemplifica falando que vai começar pela humanização dos impostos, pois no seu entender foram "elevados exageradamente e estão criando problemas para os humildes que não podem pagá-los". (idem) O candidato não explica o que significa humanizar os impostos. No discurso, ele diz defender os interesses dos mais humildes, que não podem pagar tributos tão altos, mas não esclarece como fará isso. E em nenhum momento propõe aumentar a tributação dos ricos, por exemplo.

Belinati também faz questão, nesse mesmo debate, de se identificar com a camada mais pobre da população: "A nossa campanha é a mais pobre. O candidato mais pobre 
desta jornada política é este que tem a honra de falar agora aos maçons. Isto não nos desmerece. Estamos lutando numa campanha tão pobre que, às vezes, nos falta até dinheiro para comprar a cola necessária para pregação dos nossos cartazes. Mas nossa campanha tem sido apoiada pelo povo, que quer ser livre, que sabe que não vai encontrar um prefeito de portas fechadas. (...) Portanto, posso afirmar, de consciência tranqüila, que não temos e jamais teremos qualquer vinculação com grupos econômicos”. (idem)

O candidato insiste não só em dizer que vai governar para os pobres, como ressalta que ele é o mais pobre entre os que concorrem à prefeitura, e que não há qualquer demérito nessa condição. Ao declarar-se pobre, Belinati se credencia como o mais indicado para resolver os problemas dos pobres. Afinal, ele bem entende o que é a pobreza. A campanha de Belinati é pobre - afirma - mas conta com o apoio do povo. Conforme M. Thiollent, em Opinião pública e debates políticos, no discurso político, a referência à classe social não pode ser concebida ingenuamente. "(...) o discurso não é encarado como se fosse uma 'emanação' espontânea da classe. O referencial de classe relacionado com o discurso faz parte de um sistema sócio-político e da própria luta que se desenrola na sociedade". (THIOLLENT, 1986, p.51)

Cabe destacar que, na campanha de 1996, conforme a declaração de bens dos candidatos a prefeito publicada pela Folha de Londrina, Belinati é o mais rico entre eles. Sob o título "Bernardo é o mais pobre dos candidatos - Bens do candidato petista somam $\mathrm{R} \$ 128$ mil. Belinati é o mais rico, com patrimônio de R $\$ 490$ mil", segue a relação de bens dos candidatos. (BERNARDO É O MAIS POBRE..., 1996, p.5)

A campanha de Belinati em 1996 também já não é a mais pobre. De acordo com a declaração de previsão de gastos apresentada à Justiça Eleitoral, a coligação de Belinati pretendia gastar R $\$ 840$ mil, ficando abaixo apenas da coligação de Hauly (com planejamento de R\$990 mil).

No mesmo discurso feito aos maçons, em 1972, Belinati afirma que o povo quer ser livre e sabe que, com ele como prefeito, vai encontrar as portas abertas. Portanto, o candidato reforça que é o candidato ideal para os pobres e que vai libertá-los (ele não explica do quê).

Em "A análise de conteúdo da mensagem", capítulo 18 de Comunicação e indústria cultural, Philip J. Stone fala que as palavras contêm a "significação da natureza, disposição e interesse daquele que fala". A "natureza de quem fala" inclui características de personalidade e estilos de expressão, derivados em parte da experiência passada do indivíduo na família, vizinhança, escola e trabalho. (STONE, 1975, p.318)

Segundo o autor, devido ao desejo de colocar em palavras uma idéia, o indivíduo seleciona aquelas mais relevantes para suas próprias associações, bem como as mais aceitáveis e relevantes para as associações de seus interlocutores. É o que Belinati faz. Ele escolhe bem as palavras: "humanizar os impostos", "governar de portas abertas", "a nossa campanha é a mais pobre", "a pobreza não nos desmerece", "o povo quer ser livre".

Essa argumentação usada por Belinati é de apelo popular. Segundo M. Thiollent, os apelos populares são freqüentes nos discursos políticos, "em particular nos de ten- dência populista (assumida ou não). Mas também existem em outras tendências". (THIOLLENT, 1986, p.84) Thiollent apresenta a preocupação de D. M. de Souza Filho ao abordar a questão da "vontade popular" a partir de princípios de filosofia da linguagem. (SOUZA FILHO apud THIOLLENT, 1984, p.84)

Com base em Souza Filho, Thiollent afirma que, no discurso político, “a entidade coletiva 'povo' se torna 'sujeito', em expressões tais como 'o povo exige reformas', 'o povo sabe', etc.” (THIOLLENT, 1986, p.84) O autor diz ainda que, conforme a filosofia da linguagem ordinária, este tipo de frase é problemático e até "falacioso". Thiollent cita Copi para definir falácia: "uma forma de raciocínio que parece correta, mas que, quando examinada cuidadosamente, não o é". (COPI apud THIOLLENT, 1986, p.77) Portanto - continua Thiollent - os argumentos falaciosos não possuem consistência lógica e correspondem a "erros" de raciocínio. "Contudo, em situação polêmica, os interlocutores conseguem exercem com eles efeitos pragmáticos muito fortes. Seu uso, quase espontâneo por parte dos políticos, mostra que, além de 'erro' lógico, os argumentos e raciocínios considerados possuem 'outra lógica' não contida na frase e sim na interação social que lhe é subjacente”. (THIOLLENT, 1986, p.77)

Belinati se empenhou em construir uma imagem de candidato mais pobre. No dia da eleição de 1972, o comitê pró-Belinati publicou matéria paga com algumas frases de efeito: "Belinati é a luta do tostão contra o bilião (sic) do chefão" e "Chegou a hora e a vez do povo: É Belinati". (O POVO JÁ DECIDIU..., 1972, p.3)

No pleito de 1976 , quando Belinati finalmente elegeu-se prefeito, a revelação de que ele não era o candidato mais pobre causou uma grande surpresa. $\mathrm{O}$ mais pobre era Mário Stamm, que também disputou a eleição em 1972. Ou Belinati considerava-se realmente o mais pobre e por isso divulgava o fato como se fosse verdade, sem uma análise da realidade, ou em quatro anos o seu patrimônio cresceu e suplantou o de Mário Stamm.

Oito dias antes da eleição, no dia 7 de novembro de 1976, a Folha traz matéria sobre a declaração de bens dos candidatos a prefeito. A matéria - manchete da edição - é publicada na página 8 , com o seguinte título "Wilson é o candidato mais rico (E Belinati não é o mais pobre)". Wilson a que se refere o título é o candidato Wilson Moreira, que em 1982 elegeu-se prefeito de Londrina. O fato de o título ressaltar que Belinati não é o mais pobre entre os candidatos significa que predominava em Londrina a idéia de que ele dispusesse de menos bens que seus adversários.

Essa imagem, que não correspondia à realidade, foi construída pelo próprio candidato desde que entrou na vida pública, uma vez que a origem dele é humilde ("filho de ferroviário"). Em artigo publicado no dia 11 de novembro de 1976, o advogado Hamil Adum refere-se à publicação dos bens dos candidatos, defendendo que talvez um rico tenha melhores condições de recusar pressões escusas.

"O que sim deveria levar-nos à surpresa é a não pobreza (tão badalada por aî) de um dos candidatos. Viu-se por sua relação de bens que ele não é tão pobre como sempre procurou aparentar ser". O articulista continua: "Por que 
então o receio, o medo quase pânico de ser revelado ao povo, ao eleitor como um novo rico a caminho de tornar-se um próspero burguês? Para captar o voto do pobre? Para que as massas se condoessem dele?" (ADUM, 1976, p.2)

Hamil Adum fala que não aceita a "ojeriza e o preconceito" contra o rico. "Mais grave, porém, é quando se pretende passar por pobre, ou se explora essa condição, para se chegar aonde (sic) se pretende. Porém, mais do que grave, torpe - para não dizer a suprema torpeza - quando se busca fazer de candidatos ricos os inimigos públicos número um, enquanto aqueles que assim procedem, alucinando as massas com sua demagogia franciscana, de sandália ou chinelo, já vão fazendo seu pé de meia, encontrando-se a meio caminho da riqueza, quando não já nela (sic)". (idem)

A imagem de candidato pobre, representante dos pobres, já estava consolidada mesmo em 1972. A edição da Folha de Londrina de 17 de novembro, quando já era conhecido o resultado da eleição, analisa que a derrota de Belinati para José Richa foi em decorrência da chuva do dia 15, que impediu que um grande número de eleitores da zona rural votasse. "A abstenção da cidade não foi grande, mas na zona rural 43 por cento deixaram de votar por causa da chuva, prejudicando o candidato Antonio Belinati, que seria agora o novo prefeito caso fosse de sol o dia das eleições, eis que a diferença sobre (sic) Richa foi de apenas 1.880 votos". (LONDRINA..., 1972, p.1)

Em 1972, Richa teve 16.684 votos; Belinati, 14.804; Álvaro Dias, 8.236; e Mário Stamm, o único da Arena, 25.125. Embora tenha sido o mais votado, Stamm perdeu para a soma dos três candidatos do MDB, conforme a legislação eleitoral da época, que privilegiava o voto na legenda partidária. Londrina tinha 84 mil eleitores.

$\mathrm{Na}$ mesma edição, outra matéria da Folha reforça a idéia do candidato do povo, do morador da periferia e da zona rural: "Com 73 urnas apuradas, muitos partidários de 'Belinati ainda confiavam em sua recuperação, tendo em vista que a maioria das seções pertenciam ao centro da cidade, onde era notório que seu candidato não seria bem votado". (PRIMEIRO VOTO..., 1972, p.12) Essa afirmação, feita pelo jornal, ajuda a consolidar a imagem de Belinati como o candidato do povo.

No dia 18 de novembro de 1972, na capa da Folha, há uma matéria de repercussão da eleição com o candidato derrotado, Antonio Belinati. Em entrevista ao Jornal, ele diz: "Ganhou o partido, estamos satisfeitos. Aqui na Assembléia continuaremos defendendo Londrina e prestigiando o prefeito, e queremos que ganhe o povo. Mas pedimos a José Richa que cuide também da nossa gente, daqueles que nos proporcionaram tão expressiva votação e que contribuíram para a vitória do prefeito eleito, voto (sic) sem os quais o MDB não venceria em Londrina. Temos também responsabilidade direta pela eleição de José Richa. Ela também nos pertence. Vamos trabalhar unidos nas boas causas. $O$ povo confia, não podemos frustrar com (sic) os anseios de toda esta gente e que ainda confia nos políticos. Muito obrigado aos eleitores. Aos que votaram, e aos milhares que, em virtude da chuva, não puderam nos dar o voto. (...) Ainda estamos exercendo um mandato que o povo nos confiou". (BELINATI: QUE RICHA..., 1972, p.1) Com essa fala,
Belinati apresenta-se como o político digno da confiança da população.

Em Opinião pública e debates políticos, Thiollent, conforme estudos de D. M. de Souza Filho, afirma que o apelo ao povo, no discurso político, funciona como "argumento de quem estiver interessado em exercer determinados efeitos políticos". (THIOLLENT, 1986, p.85) O autor cita também que a referência ao povo faz parte de um procedimento argumentativo de tipo apelativo no plano emocional. É fácil encontrar nas atitudes e falas de Belinati um apelo emocional ao eleitor, principalmente o mais pobre.

$\mathrm{Na}$ eleição de 1976, a análise do material jornalístico fica um pouco prejudicada devido à Lei Falcão, que restringe a divulgação da campanha dos cinco candidatos à Prefeitura de Londrina (três da Arena e dois do $\mathrm{MDB}$ ). Como durante a campanha o jornal não publicou sequer uma linha a respeito de discursos e comícios dos candidatos, a primeira declaração do candidato Belinati ocorreu quando já estava eleito.

Na edição de 17 de novembro, a Folha publica matéria intitulada "Deus e o povo me escolheram para administrar Londrina". No texto, Belinati declara: "Nesta cidade existem milhares de homens capazes para dirigi-la. Eu fui o escolhido por Deus e pelo povo para administrá-la e farei todo o possível para retribuir ao povo a confiança que depositou em mim". (DEUS E O POVO ME ESCOLHERAM..., 1976, p.3) A partir dessa vitória, o viés religioso passa a ser visto com frequiência nos discursos de Antonio Belinati. Ele coloca-se como ungido por Deus para governar Londrina, uma vez que vai agir em benefício da população mais carente.

Dos 119.218 eleitores de Londrina, votaram 98.648. Belinati recebeu 36.356 votos; Wilson Moreira (também do MDB), 26.192; Manoel Garcia Cid (Arena), 21.986; Mário Stamm (Arena), 9.686 votos; e Pedro Vasconcelos (Arena), 1.415. Sozinho, Belinati fez mais votos que a soma dos três candidatos da Arena.

$\mathrm{Na}$ eleição de 1988, o então prefeito Wilson Moreira (PMDB) apoiou o candidato de seu partido, José Tavares. Os outros candidatos foram: João Scaff (PDS); Walter Motta Campos (PTB) e Alcides Carvalho (PT). Belinati, já no PDT, coligava com PL, PFL, PDC e PMC.

Foi uma disputa acirrada. Tanto que a diferença entre Belinati e José Tavares, que ficou em segundo lugar, foi de 788 votos. Mas a campanha não é tão noticiada no Jornal. No dia 9 de novembro de 1988, a Folha publica matéria que informa que o prefeito Wilson Moreira e seu chefe de gabinete Wilson Oliveira levaram uma pedrada após a inauguração de uma obra pública. O então prefeito atribui a agressão aos partidários de Belinati, que obviamente negou a participação de seus correligionários em qualquer provocação.

Segundo o candidato, sua campanha é baseada "na paz e no amor”. “(...) nós não vamos entrar nessa - afirmou [Belinati] - e, como cristãos, somos contra agressões a qualquer pessoa, principalmente contra o prefeito Wilson Moreira." (E BELINATI DIZ... 1988, p.3) É interessante observar que, ao longo da carreira de Belinati, vão aumentando gradativamente os ataques contra ele vindos dos adversários políticos. E mais uma vez Belinati apela à religiosidade para justificar por que os correligionários dele não adotariam uma atitude agressiva durante a campanha eleitoral. 
$\mathrm{Na}$ entrevista ao prefeito Belinati para este trabalho, a autora fez a seguinte pergunta: Por que o senhor sempre fala como se tivesse sido escolhido por Deus para governar Londrina? Belinati afirma que não é intuição ou opinião dele. “(...) Sou da Igreja Metodista. Se Deus não quiser, ninguém jamais será eleito. (...) Quem não conhece a Bíblia pode achar até que é pejorativo falar que depende de Deus a minha eleição. Mas eu acho que na nossa vida nada será feito que não seja da vontade do Pai." (BELINATI, 1999)

Em 1996, Belinati volta a sofrer ataques duros dos adversários e a falar de "paz e tranquiilidade". De acordo com matéria sobre debate ocorrido na Associação Comercial e Industrial de Londrina, Hauly disse: "O prefeito que construiu o conjunto Jamile Dequech devia estar na cadeia". (PACCOLA, 1996b, p.4) O Jamile Dequech, que fica muito distante da área central, foi construído durante a segunda gestão de Belinati.

E Belinati novamente apela para os sentimentos para contra-atacar. Conforme a matéria da Folha, Belinati informou que "sua equipe "está no caminho certo, com uma campanha traduzindo paz, tranqüilidade e sobretudo uma campanha para cima. (...) O desespero é dos adversários e isto fica muito caracterizado nas campanhas deles, marcadas por ataques e violência"'. (OGAMA, 1996c, p.4)

Cinco dias antes das eleições de 1988, matéria da Folha retrata o clima pesado da campanha. Abaixo do título "Olha o nível", segue uma abertura que diz: "Brigas em palanques, políticos apedrejados, troca de acusações nos comícios, no rádio e na televisão, guerra fria de panfletos e 'mal-feitos'. Londrina não vive só uma campanha, vive uma batalha eleitoral". (OLHA O NÍVEL, 1988, p.30)

Entrevistado pelo Jornal, Belinati aproveita para associar o candidato José Tavares, apoiado pelo prefeito Wilson Moreira, a medidas antipopulares. "(...) O candidato pedetista Antonio Belinati, há 20 anos disputando eleições na cidade, garante nunca ter visto nível tão baixo numa campanha. (...) Ele acusa o PMDB de incitar violência ao levar um 'enorme aparato policial nos comícios, como se o povo londrinense fosse marginal. E o povo - acrescenta - é claro que fica descontente com uma atitude dessas de um candidato a prefeito'. Mas insiste que a agressão ao prefeito Wilson Moreira partiu de gente do próprio PMDB, 'para criar uma emoção social', que revertesse o quadro atual, que garante ser amplamente a seu favor". (idem)

Belinati aponta o preconceito do adversário contra os mais pobres, ao falar que os comícios de Tavares tinham policiamento. Ele faz a defesa dos eleitores de baixa renda, que votam nele, e passa a idéia de que esse povo é cordato, humilde e que não faz uso da violência. $O$ candidato colocase no lugar desses eleitores e fala do sentimento que os abate quando são tratados como marginais.

No capítulo 3 - "Sociologia e análise da linguagem" — da obra Opinião pública e debates políticos, M. Thiollent afirma que as características de linguagem próprias aos membros de determinada classe podem indicar como é empenhada a linguagem nas relações de poder, em particular no que diz respeito às práticas que visam estabelecer consenso ou hegemonia e as que visam dividir ou "aniquilar" adversários. (THIOLLENT, 1986, p.49)
Thiollent diz ainda que um discurso pode ser interpretado como momento da relação ideológica de um autor procurando apoio das massas, sedução de possíveis aliados ou desmoralização de adversários. Além disso - segundo Thiollent - o discurso desempenha uma importante função na justificação de posições de classe e também na ocultação ou destruição das posições das outras classes. (THIOLLENT, 1986, p.50)

No dia 17 de novembro de 1988, a capa da Folha tem o seguinte título "Belinati vence por apenas 838 votos". "Na mais disputada apuração acontecida em Londrina, o deputado estadual Antonio Belinati (PDT) acabou eleito prefeito, com uma virada que surpreendeu o próprio candidato". (BELINATI VENCE..., 1988, p.1) O jornal relata que até as 17 horas, José Tavares (PMDB) liderava a apuração e ia ampliando a vantagem, chegando a ficar com mais de $13 \mathrm{mil}$ votos na frente. Mas, quando começaram a ser computados os resultados da $157^{a}$ Zona Eleitoral, que se localiza na região dos Cinco Conjuntos, a vantagem foi caindo, até que Belinati passou à frente, com 68.694 votos, contra 67.856 para Tavares.

O total de eleitores era de 202.909; votaram 183.324. Os outros candidatos obtiveram a seguinte votação: João Scaff, 13.328; Alcides Carvalho, 8.375; Walter Campos, 1.139. Houve 7.075 votos nulos e $16.856 \mathrm{em}$ branco.

No dia 18 de novembro de 1988 , a capa da Folha mostra uma foto de Belinati sendo carregado nos braços, com a legenda: "Na madrugada, o povo dos Cinco Conjuntos faz festa com Belinati". O texto diz que a industrialização será a locomotiva da próxima administração municipal. O prefeito eleito - conforme o texto - "assegurou também 'amplo atendimento à camada periférica da cidade', responsável por sua vitória nas urnas" contra José Tavares. "Belinati afirmou que também dará especial atenção aos menores abandonados e mendigos". (AS METAS..., 1988, p.1)

Na página 3, desse mesmo dia, o título da matéria é "Conjuntos comemoraram a vitória de Belinati", que fala sobre a festa na avenida Saul Elkind, da vitória do prefeito. " O apoio que o Tavares teve foi do pessoal do centrão e das autoridades; o apoio do Belinati foi da periferia que é pobre e que quando abre a marmita só tem ovo' - gritou um morador entusiasmado (...) Dona Francisca de Jesus, 72 anos, rezou para Santo Antonio durante a apuração, pois, segundo ela, 'ele é o santo do Antonio Belinati'”. (CONJUNTOS COMEMORARAM..., 1988, p.3)

No dia 22 de novembro, a folha publicou que a Justiça Eleitoral proclamou oficialmente os resultados das votações, que davam uma diferença entre os dois candidatos de 788 votos e não de 838 como se noticiou logo após a apuração.

A vitória apertada de Belinati não condiz com o otimismo do candidato, declarado um dia depois da eleição. Matéria de 16 de novembro, da Folha, tem o título: "Belinati acredita que já venceu”. No texto, Belinati afirma não ter dúvida de que seria o vitorioso. (BELINATI ACREDITA..., 1988, p.4) Em entrevista concedida à autora do trabalho, em 1999, Belinati fala que não considera que "quase perdeu" para Tavares, em 1988.

"Eu tive uma grande vitória porque eu não podia ganhar aquela eleição. Não tinha como ganhar. O candidato

Rev. Mediações, Londrina, v. 4, n. 2, p. 19-31, jul./dez. 1999 
Tavares sai apoiado pelo todo poderoso e consagrado como prefeito, imbatível, o melhor prefeito do mundo, Wilson Moreira, com apoio do governador do estado, apoio de ministro, de quase toda a Câmara de Vereadores, apoio de toda estrutura econômica que você pode imaginar. Aí saio eu, lá, com dificuldade de montar um palanque. A gente vai e bate em toda essa estrutura. Eu diria que eu estava inclusive psicologicamente preparado para disputar sabendo que era difícil mesmo. (...) Então eu diria o seguinte: o outro lado perdeu. (...) Houve, sim, acho que pela primeira vez, um divisor muito grande do eleitorado, de tal maneira que essa faixa elitizada do eleitorado trabalhou maciçamente para o nosso adversário e, quando ele ia fazer um comício nas áreas populares, tinha que botar polícia, segurança, tinha quebra-quebra, pancadaria, e nos meus comícios o povo vinha com flores, com carinho. Então houve uma separação muito grande. Foi a primeira vez que eu vi na história da cidade esse divisor. (...)". (BELINATI, 1999)

Nas eleições de 1996, ele concorreu com o candidato do PSDB, deputado federal Luiz Carlos Hauly; deputado estadual José Tavares (PMDB); e deputado federal Paulo Bernardo (PT). Belinati era da coligação Londrina Terra da Gente, que reunia PDT, PTB, PPB, PSD, PST, PSB, PSC e PSL. Em 16 de agosto, matéria da Folha diz: "O candidato à Prefeitura de Londrina, Luiz Carlos Hauly (coligação Por Amor a Londrina), afirma que seu crescimento de $11,8 \%$ para $16,2 \%$, segundo pesquisa do instituto Alvorada publicada ontem na Folha, indica que ele vai vencer a eleição no primeiro turno." (PACCOLA, 1996a, p.4)

Conforme a matéria, Belinati não estava preocupado em ser eleito no primeiro ou no segundo turno. "Essa preocupação não é minha. É dos meus concorrentes". Belinati diz ainda que haveria segundo turno em Londrina se o segundo colocado atingisse $35 \%$ dos votos no dia 3 de outubro. "Ele está muito longe dessa meta e seu crescimento está sendo muito lento. Deveria estar com 25\% agora". (idem)

O texto diz ainđa que, segundo Belinati, sua posição nas pesquisas é melhor do que a de qualquer candidato a prefeito em cidades médias e grandes. "“Acompanho a publicação de pesquisas de vários institutos e nenhum candidato tem o meu índice de aprovação. Louvo a Deus pelo carinho, amor e confiança do povo por mim e pelo Alex' (Canziani, candidato a vice)". (idem) Belinati mais uma vez atribui o apoio popular a uma bênção de Deus.

Thiollent analisa que o argumento "o povo está comigo" é mais tendencioso no caso de ser pronunciado por um candidato com $1 \%$ de preferência do eleitorado do que no caso de outro candidato com $51 \%$. "Mas em ambos os casos, é preciso salientar que se trata de um procedimento argumentativo. (...) mesmo neste último caso, podemos questionar o argumento em função dos $49 \%$ de eventuais opositores". (THIOLLENT, 1986, p.86)

Em matéria publicada em 4 de agosto de 1996, a Folha divulga resultado de pesquisa que apresenta também o perfil do eleitorado de Belinati: "Como era de se esperar (grifo meu), Belinati tem o maior percentual da intenção de votos na zona norte $(64,7 \%$ na pesquisa estimulada). A intenção de voto no candidato do PDT é menor no Centro, onde 33,3\% dos eleitores pretendem votar nele". O texto revela outra informação que confirma a liderança de Belinati: "A pesquisa mostra também que há eleitores que não votam no candidato do PDT mas acreditam que ele vá vencer o pleito. Indagados sobre quem acham que vai ganhar a eleição, 74\% responderam Belinati; 5,3\%, Hauly; 1,5\%, Tavares; e 0,8\%, Bernardo". (LOMBA, 1996b, p.4)

Esse clima de "já ganhou” também esteve presente na eleição de 1976. Matéria de cobertura da eleição, publicada no dia 16 de novembro na Folha, diz: "Desde cedo a 'onda' de que Belinati já estava eleito começou a ganhar corpo, e isto deve ter beneficiado o candidato, pois ouvia-se muitos eleitores novos que (...) [iam votar no Belinati] 'para não perder o voto"”. (MDB SAI..., 1976, p.1)

A matéria sobre o comitê eleitoral, de 1976, enfatiza o grande número de pessoas presentes: "O que faz com que o cheiro de suor torne o ar sufocante. (...) 'Aqui é comitê de gente pobre e doente. A gente tem que se contentar com que o Belinati vai dar pra gente' - disse ao repórter um admirador incondicional de Belinati". (BELINATI É O PREFEITO?, 1976, p.2) Ao retratar o ambiente do comitê, a matéria reforça a ligação do candidato com as pessoas de baixa renda. Os eleitores, admitindo a própria condição de pobreza, conformam-se em ter Belinati como alguém que vai resolver o problema deles.

Em O populismo na política brasileira, Francisco Weffort analisa o processo político e as eleições de Getúlio Vargas, Jânio Quadros e Adhemar de Barros. "As massas (...) reivindicam um Estado impessoal mas enquanto se mostram incapazes de reconhecer sua condição real de classe, só encontram meios de exprimir-se através do carisma, ou seja, através da mais irracional das formas de manifestação política. Jogam toda a sua aspiração de mudança política em uma pessoa que imaginam dotada de um poder ilimitado". (WEFFORT, 1980, p.35-36)

$\mathrm{O}$ atendimento aos eleitores começa na própria campanha de Belinati. Conforme a reportagem, o comitê estava cheio de gente porque providenciava o transporte dos eleitores. A matéria diz: "um dos elementos mais ativos do comitê dá a boa notícia ao 'povão'. Sobe na cadeira (...): 'Atenção povão morto-de-fome. Vai vim (sic) sanduíches aqui pra todo mundo"'. (BELINATI É O PREFEITO?, 1976, p.2)

Weffort fala que em 1945 inicia-se no país uma democracia "em que é preciso 'cortejar' as massas". (WEFFORT, 1980, p.22) Belinati se enquadra entre aqueles políticos que não fazem corte às massas apenas no discurso, mas resolvem alguns problemas imediatos dos eleitores, como o transporte e a comida.

No livro Sociologia da comunicação, Gabriel Cohn, no capítulo 4 ("A dimensão social: a sociedade de massas"), cita a pesquisa The people's choice, de Lazarsfeld, Berelson e Gaudet, que conclui: "Pessoas que convivem sob condições externas similares são suscetíveis de desenvolverem necessidades e interesses similares. Tendem a aplicar interpretações comuns a experiências comuns". Segundo o autor, os integrantes "se ajustam ao caráter político do seu grupo sob a influência persistente e pessoal dos concidadãos mais ativos politicamente". (COHN, 1973, p.76)

Outra matéria, também do dia 16, acompanhou a votação dos cinco candidatos. Durante a de Belinati, uma mu- 
lher que acabara de votar procurou o candidato e reclamou que não havia condução para levá-la de volta para sua casa. Belinati não teve dúvidas: ofereceu o carro que o trouxera. O texto afirma que à saída do local, Belinati observou "São Pedro está ajudando", numa referência ao bom tempo. Provavelmente também se lembrando da eleição de 1972. (CINCO ELEITORES..., 1976, p.2)

\section{NA ERA DO MARKETING}

A eleição de 1996 para prefeito é bastante diferente das anteriores. A própria cobertura da campanha feita pelos jornais é mais intensa. No período da ditadura militar, a referência às eleições municipais era mínima: a Folha dava bem mais destaque às eleições para presidente nos Estados Unidos do que à de prefeito, por exemplo. As primeiras matérias sobre a eleição em 1972, em 1976 e até em 1988 apareciam no jornal apenas em novembro, ou até mesmo na semana em que ocorreria a votação.

Em 1996, quando as campanhas eleitorais viraram "shows", as primeiras matérias surgem no Jornal já no mês de julho. São textos mais completos, que falam dos programas eleitorais nas TVs e rádios e dos comícios.

Em 7 de agosto de 1996, a Folha publica matéria com o título "Frases de efeito invadem programas", que se refere ao horário eleitoral gratuito, "repleto de referências à religiosidade dos candidatos e seu amor às crianças". Conforme o texto, os candidatos falam da "origem cristã, raiz pioneira e forte relação familiar". Relatam o passado político: "o que fiz quando fui isso, o que tentei fazer quando fui aquilo. A poção é enriquecida com imagens, muitas cenas que retratam homens acessíveis, simpáticos, tolerantes até ao assédio de dezenas de crianças que aparecem não se sabe de onde e vão ao encontro deles". (OGAMA, 1996a, p.5)

Segundo a Folha, nos primeiros programas de Antonio Belinati no horário eleitoral gratuito, o que mais desperta a atenção é o bando de crianças correndo em sua direção. Belinati, no primeiro programa eleitoral da TV, usou seu tempo para lembrar as obras realizadas em seus dois mandatos anteriores e para mostrar como é conhecido pela população londrinense.

O uso do marketing político foi a grande característica da primeira eleição direta, após o fim da ditadura militar, em 1989, com a polarização dos candidatos Fernando Collor de Melo (PRN) e Luiz Inácio Lula da Silva (PT). No artigo "Política, marketing e neoliberalismo", publicado na Revista Mediações, Pedro Roberto Ferreira analisa como o marketing político-eleitoral contribui para o esvaziamento da prática política. "Simultaneamente a uma 'despolitização' das práticas efetuadas pelos partidos políticos, nota-se um avanço do denominado 'marketing político' que somente reitera esta característica." (FERREIRA, 1996, p.16)

Segundo o autor, no mesmo artigo, a utilização do marketing político "deslocou o debate que (...) girava em torno das propostas dos partidos políticos, para as técnicas de compra/venda geralmente empregadas no envolvimento dos consumidores postos pelo mercado capitalista". (idem)
Na análise de Pedro Roberto Ferreira, a "despolitização" da sociedade civil vai ao encontro dos anseios da classe dirigente, e o marketing político vem reforçar essa tendência.

Em 21 de agosto de 1996, a Folha publica reportagem que relata como foi um dia de campanha de Antonio Belinati. A reportagem acompanhou o candidato em todos os seus compromissos marcados no dia 17 de agosto, um sábado. Segundo o repórter, a agenda de Belinati teve início às 9 horas com a participação em um debate promovido pela Associação Comercial e Industrial de Londrina, junto com a Folha e a TV Londrina.

Após o debate, Belinati vai a um churrasco. De acordo com a reportagem da Folha, Belinati faz do churrasco, "antes animado apenas por músicos sertanejos", um show. Todas as atividades estão sendo gravadas por uma equipe de produção do programa eleitoral do candidato. $\mathrm{O}$ candidato não perde a oportunidade de conversar e brincar com as pessoas. Conforme a matéria do jornal, Belinati pergunta aos presentes: "Quem é que sabe o nosso número pra prefeito?" E, em seguida, ensina como se faz para votar no número dele - 12 - usando a urna eletrônica. De maneira bem didática - segundo o Jornal - Belinati repete várias vezes a aula para que os eleitores votem corretamente. (OGAMA, 1996b, p.4)

O candidato sabe que a maioria do seu eleitorado faz parte da camada mais pobre e, portanto, pode ter mais dificuldade no momento de votar na urna eletrônica. Após o primeiro turno de 1996, Belinati atribuiu à urna eletrônica o fato de haver segundo turno na cidade. Em entrevista à Folha, o candidato Belinati disse: "A urna eletrônica, que levou um grande percentual de eleitores a anular ou votar em branco, nos tirou a vitória no primeiro turno". (PACCOLA, 1996c, p.4)

A posição dele diante do eleitorado de baixa renda foi publicada pela Folha em 16 de agosto de 1996. Pesquisa realizada pela Alvorada, sob encomenda do jornal, aponta que vão votar em Belinati, no segundo turno, 60,8\% dos eleitores sem renda e $61,6 \%$ dos com renda entre um e três salários mínimos. (LOMBA, 1996c, p.4) Na edição seguinte, a Folha noticia que cresce o número de eleitores de Belinati entre os analfabetos. "Os analfabetos que dizem votar em Belinati aumentaram de $50 \%$ para $76 \%$. Belinati cresceu também entre os com segundo grau incompleto, passando de 43,1\% para 49,4\%". (TAVARES PERDE VOTOS..., 1996, p.4) Embora tenha diminuído o número de eleitores que têm o primeiro grau incompleto, é um índice ainda alto: $55,9 \%$.

"Entre os eleitores com renda acima de dez salários mínimos, a preferência por Belinati cai para $36,8 \%$, a mais baixa do candidato neste critério. Os que votariam em Hauly num segundo turno contra Belinati são mais numerosos entre os com renda entre sete e nove mínimos $(38,6 \%)$ e acima de dez mínimos (36,8\%). A preferência por Hauly é menor entre os eleitores sem remuneração $(18,5 \%)$ e é diretamente proporcional ao aumento da renda". (LOMBA, 1996c, p.4)

Nessa campanha, a distinção entre Belinati e seu principal adversário - Luiz Carlos Hauly - não ocorre apenas segundo a classe social e a formação escolar do eleitor de cada um. Os dois apresentam-se em posições diferentes diante de esferas maiores da política. Belinati é o candidato dire- 
tamente ligado ao governador do Paraná, Jaime Lerner - a esposa de Belinati é a vice-governadora - e Hauly, ao presidente da República, Fernando Henrique Cardoso (PSDB).

No único debate que reuniu os quatro candidatos à prefeitura em 1996, em julho, ficou explícita essa ligação dos candidatos com o governador e com o presidente. A matéria da Folha sobre o debate foi publicada em 17 de julho. "Ficou clara a estadualização e a federalização da eleição. De saída, Hauly e Belinati impuseram um ao outro a 'pecha' - mutuamente aceita - de candidato do governo federal e do governo estadual, respectivamente". (LOMBA, 1996a, p.4)

Ser "amigo" do governador ou do presidente da República tem um forte apelo na busca por votos. No livro $O$ poder do atraso, José de Souza Martins fala que "a política do favor, base e fundamento do Estado brasileiro, não permite nem comporta a distinção entre o público e o privado". (MARTINS, 1994, p.20) Essa "disputa" entre Hauly e Belinati para ver quem goza de mais prestígio junto ao governador ou ao presidente só tem razão numa sociedade em que o público e o privado misturam-se e onde os partidos têm fraco apelo para o eleitor.

No Brasil, há uma supervalorização do Poder Executivo em detrimento do Poder Legislativo. Portanto, o então deputado estadual Belinati e o deputado federal Hauly demonstram a sua relação com o Poder Executivo - o governador e o presidente. Em "Clientelismo e política no Brasil: revisitando velhos problemas", George Avelino Filho fala da relação "particularista e individual" que os parlamentares têm com o aparelho do Estado, o que mostra a "fragmentação da representação reforçada pelo federalismo jurídico e pelo regionalismo político". (AVELINO FILHO, 1994, p.233)

A legislação eleitoral brasileira - avalia o autor reforça essa tendência à atuação individual entre os parlamentares. Avelino Filho cita Mainwaring que, ao estudar comparativamente a influência do sistema eleitoral sobre o funcionamento dos partidos políticos, destaca o caso brasileiro "como um dos que mais dificultam os esforços para a construção de partidos mais efetivos, através do incentivo ao individualismo entre os parlamentes e do conseqüente enfraquecimento de suas relações com os partidos a que pertencem". (MAINWARING apud AVELINO FILHO, 1994, p.232)

Ainda tratando desse assunto, Avelino Filho afirma que a relação individual que os parlamentares estabelecem com o Executivo, para obter recursos para suas "bases eleitorais", é de fundamental importância para a sobrevivência e lealdade das organizações partidárias locais, o que lhes permite controlar a competição política em seus redutos. Essa avaliação explica melhor a preocupação de Hauly e Belinati em mostrar para o eleitor a ligação com os Executivos em instâncias superiores.

\section{3. "EU PROMETO"}

Se na fala genérica de Antonio Belinati ele ressalta sempre a defesa do povo de baixa renda, as promessas de obras e serviços também são voltadas para os mais pobres.
Em 1996, Belinati promete trocar 20 mil fossas sanitárias por esgoto. Para a educação, promete cursos de alfabetização para adultos e escolas de informática gratuitas para crianças. (CANDIDATOS DEBATEM..., 1996, p.4) Em 11 de novembro de 1972, no debate com os maçons, surgiu uma pergunta a Belinati sobre como resolver o problema da fila do então INPS, tratando-se de um instituto ligado ao governo federal.

"Parto do princípio de que a saúde do povo é um problema que afeta a qualquer homem público com sensibilidade suficiente para sentir-se penalizado com o drama de pessoas humildes que dormem, às vezes, na porta do posto do INPS, enfrentam um dia inteiro de fome e penúria, para ter direito a uma consulta médica para si ou para o seu filho doente". (AS DECLARAÇÕES..., 1972, p.3) O candidato propõe-se então a fazer um convênio entre prefeitura e INPS para que funcionários do município sejam cedidos para o serviço de saúde federal.

Sobre educação, ele aponta para a mesma saída: fazer parceria com o governo do estado para a construção de mais escolas. "A Prefeitura, assim, construiria as salas de aula e as entregaria ao governo do Estado, pois não é justo que o filho do trabalhador, por exemplo, da [do distrito de] Maravilha, não tenha o direito de estudar, porque ali não foi construído um ginásio, e porque o prefeito entendeu ser problema da alçada estadual nada deve fazer para solucionar a questão. Repito o que já disse: quando se trata de resolver problemas do povo não olho se este é da alçada da Prefeitura, do Estado ou da Federação". (idem)

A proposta de se unir ao estado ou à União na busca de soluções para problemas sociais ressalta a característica conciliadora de Belinati. "Após o dia 15, se for eleito, vou lutar com todas as forças pela pacificação política do município, pois somente quem sai perdendo com tais divergências é o próprio município, daí porque prego o esquecimento das desavenças e a união de todos em busca de melhores destinos". (idem)

Nas eleições de 1996, a coligação Londrina Terra da Gente, de Belinati, cria um folheto intitulado "Você Decide" para consultar os eleitores sobre as prioridades que deve ter a próxima administração municipal. A matéria da Folha informa que são cem mil folhetos. Conforme o jornal, o formulário mostra doze pontos socioeconômicos escolhidos pela coligação como os mais importantes. O eleitor assinala as propostas que considera essenciais e depois envia a resposta ao comitê de campanha do candidato, com porte já pago. (BELINATI LANÇA..., 1996, p.4)

Ao consultar a população para definir prioridades do governo, Belinati mostra preocupação de querer governar para o povo. Segundo Landshut, a opinião pública é a única base aceita para legitimar a dominação política. "O Estado moderno põe como princípio da sua própria verdade a soberania popular, e essa por seu turno deve ser a opinião pública. Sem essa atribuição, sem a proposição da opinião pública como a fonte de toda a autoridade investida nas decisões que comprometem o todo, a moderna democracia carece da substância da sua própria verdade". (LANDSHUT apud HABERMAS, 1975, p.188)

No mesmo artigo ("Comunicação, opinião pública e poder”), publicado no livro Comunicação e indústria cultu- 
ral, Jürgen Habermas cita Fraenkel que diz: "Com o auxílio da discussão parlamentar, a opinião pública dá a conhecer ao Governo os seus desejos, e este comunica à opinião pública a sua política”. Segundo Fraenkel, "a opinião pública reina, mas não governa”. (FRAENKEL apud HABERMAS, 1975, p.189)

Em Habermas, Bantley diz que não há uma opinião pública, que não há uma atividade que reflita ou represente a atividade de um grupo ou conjunto de grupos. Bantley reclamava a falta de uma análise quantitativa a respeito das coisas realmente desejadas por grupos de pessoas. Para Schmidtchen (também em Habermas), a mesma pesquisa que diagnostica a opinião pública pode indicar os meios de manipulá-la. Na opinião dele, o material da pesquisa de opinião não se qualifica já por isso como opinião pública. (SCHMDTCHEN apud HABERMAS, 1975, p.194-195)

Habermas afirma que as opiniões quase-públicas, mesmo que sejam endereçadas a um público amplo, não satisfazem os requisitos de um raciocínio público. Enquanto opiniōes institucionalizadas, elas sempre são privilegiadas, e não alcançam uma correspondência recíproca com a massa não-organizada do "público".

\section{BELINATI E O PERSONALISMO}

Antonio Belinati não inaugura nenhum jeito novo de fazer política. O surgimento e a sustentação de líderes personalistas e carismáticos são velhos conhecidos da história da política brasileira. Em O populismo na política brasileira, Francisco Weffort afirma que o populismo no Brasil - como estilo de governo ou como política de massas "só pode ser compreendido no contexto do processo de crise política e de desenvolvimento econômico que se abre com a revolução de 1930". (WEFFORT, 1980, p.61)

Weffort analisa que a crise da economia cafeeira, na década de 30 , causada pela desarticulação do mercado externo e pelo excesso na produção interna, vai provocar uma renovação nos quadros políticos dirigentes do país. Surgem condições para o desenvolvimento do capitalismo industrial, sem entrar em choque com o setor agrário tradicional.

$\mathrm{O}$ autor aponta as classes médias urbanas como protagonistas no processo de derrubada da oligarquia rural. Mas Weffort afirma que as classes médias tradicionais brasileiras "não possuíam condições sociais e econômicas que lhes permitissem uma ação política autônoma em face dos interesses vinculados à grande propriedade agrária". (idem, p.48) Houve, assim, uma composição entre os setores urbanos e os grupos agrários dominantes. "Conseguem deslocar a representação política dos interesses cafeeiros, mas não podem negar o fato de que o café ainda é a base decisiva da economia". (idem, p.49)

O Brasil vive uma situação em que nenhum dos grupos (classe média, setor cafeeiro, setores agrários menos vinculados à exportação) detém com exclusividade o poder político. "Nestas condições, aparece na história brasileira um novo personagem: as massas populares urbanas. É a única fonte de legitimidade possível ao novo Estado brasilei- ro". (idem, p.50) O poder conquistado pelos revolucionários de 30 - conforme Weffort - só encontraria sustentação à medida que se tornasse receptivo às aspirações populares. "Aparece, assim, o fantasma do povo na história política brasileira, que será manipulado soberanamente por Getúlio Vargas durante 15 anos". (idem, p.51)

Criador da legislação trabalhista, que na verdade contempla as reivindicações dos trabalhadores desde o início do século, Getúlio Vargas vai legalizar a "questão social" e construir a idéia do "pai dos pobres". Ou seja, reconhecerá para as massas o direito de formularem reivindicações. (idem, p.51)

Conforme afirma Octavio Ianni, "os movimentos de massas e as lideranças carismáticas galvanizam o povo, além dos programas formais. Ou seja, os programas só ganham sentido quando identificados com uma pessoa, isto é, um líder; em geral, o presidente, às vezes o governador e, mais raramente, o deputado, o prefeito e o vereador." (IANNI, 1971, p.66)

Durante a ditadura de Vargas, o Estado procurou legitimar-se nas massas através da manipulação, das doações às massas e aos grupos econômicos. "A ditadura foi uma solução para a consolidação do poder pessoal de Vargas e para a instauração do Estado como soberano perante as forças sociais em presença". (WEFFORT, 1980, p.69) O fim da ditadura de Vargas, no entanto, não trouxe a redemocratização esperada pelos setores médios tradicionais. "A jovem democracia brasileira terá como fundamento a massa e como chefes os líderes populistas". (idem, p.52)

Segundo o autor, "desde 1945, qualquer político que pretende conquistar funções executivas com um mínimo de autonomia em relação aos grupos de interesse localizados no sistema partidário, deve, embora de maneira parcial e mistificadora, prestar contas às massas eleitorais." (idem, p.21) O autor cita no texto que, sob o impacto do fracasso de seu partido nas eleições de 1945, "um liberal escreveu os seguintes 'conselhos' a quem pretendia êxito na política: 'Evite por todos os meios obrigar o povo a refletir. A reflexão é um trabalho penoso a que o povo não está habituado. Dê-lhe sempre razão. Prometa-lhe tudo que ele pede e abrace-o quanto puder'." (idem, p.24)

$\mathrm{Na}$ ausência de partidos eficientes, o sufrágio tende a transformar a relação política numa "relação entre indivíduos". (idem, p.19-20) Segundo Weffort, os políticos com características populistas reivindicam para si a interpretação legítima dos interesses populares. Em entrevista à autora deste trabalho, Antonio Belinati admite que os partidos políticos não têm muita importância para os eleitores. "(...) até agora não precisei de um partido para me eleger, não precisei ficar na sombra de um partido porque o partido está forte ou porque um grupo econômico ou um grupo político está me apoiando. Isso eu posso falar com muita clareza e com muita isenção. Poucos políticos chegaram a tantos mandatos como eu cheguei no contato direto com a massa. Em vez de eu esperar que um grupo privê decida o meu futuro, o meu contato é com o povo (...)". (BELINATI, 1999)

Weffort cita a revista Cadernos do Nosso Tempo que apresenta as condições gerais para o populismo, como a "massificação", a perda de "representatividade" da "classe dirigente" e, aliada a estas duas condições, "a presença de 
um líder dotado de carisma de massas". (CADERNOS DO NOSSO TEMPO apud WEFFORT, 1980, p.26) Belinati é esse líder carismático que conquistou a simpatia e a confiança dos eleitores.

Para José de Souza Martins, em O poder do atraso, o poder pessoal e a prática do clientelismo são ainda fortes suportes da legitimidade política no Brasil. George Avelino Filho, em "Clientelismo e política no Brasil", também fala que o eleitor vota em candidatos únicos para os cargos, "de modo que a eleição ou não de um determinado candidato depende, em última análise, de seu próprio esforço sem passar pelo partido". (AVELINO FILHO, 1994, p.232)

Há outras semelhanças entre a análise do populismo de Weffort e a avaliação de Belinati sobre sua prática. Weffort diz: "Na impotência histórica da pequena burguesa está a raiz da demagogia populista. Não obstante, o mais hipócrita dos populistas nunca pode ser totalmente infiel à sua massa; ele trairá, mas há limites para a traição além dos quais a imagem do líder começa a se dissolver". (WEFFORT,1980, p.34) Belinati tem plena consciência de que não pode frustrar a população que o procura.

A entrevista concedida à autora do trabalho ocorreu logo após o prefeito ter recebido os índios kaingang de uma reserva de Londrina, que reivindicavam uma estrada. "Agora há pouco, com os índios kaingang, havia aquele clima de tensão e, no final da reunião, houve abraço, carinho, fotografia. É evidente que você não pode também causar uma decepção. Marquei com eles que vou a Curitiba levar a reivindicação de uma estrada. Se eu não for, eles não vão estar mais interessados em vir aqui tomar água, tomar um cafezinho, tirar fotografia. Eles vão vir de maneira agressiva, e com razão. Então, tem que ter um discurso que na prática você se empenhe o melhor possível para cumprir". (BELINATI, 1999)

Com essa prática de atender pessoalmente quem procura a prefeitura - sem intermediários — há um reforço à idéia de que a relação ocorre no nível pessoal e, não, político. A proximidade com o político também dispensa qualquer tentativa de mobilização social. “(...) a população, sobretudo migrante de áreas tradicionais e rurais, continua, de algum modo, se relacionando com a política e com os políticos em termos das concepções tradicionais que não separavam o político do protetor e provedor". (MARTINS, 1994, p.37) Sérgio Buarque de Holanda fala que, quando o governo está fundado no consentimento dos governados, os seus malefícios "dificilmente porão em grave risco a estabilidade do regime". (HOLANDA, 1972, p.189)

Em Raizes do Brasil, Sérgio Buarque de Holanda retrata o perfil do brasileiro, cordial, que tem horror à impessoalidade. "Não ambicionamos o prestígio de país conquistador e detestamos notoriamente as soluções violentas. Desejamos ser o povo mais brando e mais comportado do mundo. (...) Fomos das primeiras nações que aboliram a pena de morte em sua legislação, depois de a termos abolido muito antes na prática. (...) Tudo isso são feições bem características do nosso aparelhamento político, que se empenha em desarmar todas as expressões menos harmônicas de nossa sociedade, em negar toda espontaneidade nacional." (HOLANDA, 1995, p.177)
Se para Sérgio Buarque de Holanda essa passividade do povo brasileiro é criticada e contribui para o personalismo, Gilberto Freyre aponta essas características como positivas, uma vez que significam um modo de equilibrar os antagonismos sociais. Em Interpretação do Brasil, Freyre atribui ao longo contato dos espanhóis e dos portugueses com os árabes, mouros e judeus o equilíbrio dos elementos antagônicos no lugar da segregação. Deve vir dos mouros "a tendência de os portugueses (senhores) tratarem os escravos domésticos mais como se fossem agregados ou pessoas da família do que escravos". (FREYRE, 1947, p.70)

Freyre ressalta que as rebeliões de escravos negros no Brasil não foram tão numerosas ou violentas como em outras regiões da América, "talvez porque o tratamento dado pelos portugueses aos escravos e, mais tarde, pelos brasileiros, provocasse menos o desejo de rebelião da parte dos oprimidos". (idem, p.108) O autor destaca que nem o sistema de plantação nem o sistema de monarquia implicaram jamais, no Brasil, rígidas gradações sociais.

Belinati enfatiza que o tratamento entre o político e a comunidade deve ser avaliado pelo eleitor. Para o prefeito, o tratamento quase familiar dispensado por ele aos funcionários municipais e domésticos é sinal de respeito. Na entrevista, ele fala sobre isso: "Se quer avaliar a vida de um político você começa a avaliar o local de trabalho dele, então o que ocorre? Onde é que eu tenho o maior ponto de apoio da minha carreira política? No funcionalismo municipal. (...) Se você for lá no meu prédio e perguntar para os porteiros, $100 \%$ deles são meus eleitores. Às vezes um político tem uma imagem lá fora de simpático, cordial com o povo e pisa no pessoal que está em volta dele. (...) O povo antes de escolher um candidato deveria procurar saber como ele é dentro da sua casa, do condomínio, do seu próprio local de trabalho, porque eu já vi muita falsidade. (...)". (BELINATI, 1999)

A concepção de Belinati de como deve ser o relacionamento do político com os funcionários - públicos e privados - reforça a idéia da necessidade e do benefício do culto ao personalismo; não faz qualquer distinção entre o público e o privado.

$\mathrm{Em} O$ debate contemporâneo sobre a representação política, Marcos Novaro coloca que a democracia de partidos surgiu no início deste século, em lugar do parlamentarismo clássico. Segundo Novaro, os partidos se constituíam como organização de massa com programas e discursos ideológicos mais ou menos consistentes, "incorporaram novas dimensões de representatividade e participação ao sistema liberal-parlamentar". (NOVARO, 1995, p.79)

Na década de 90 , a crise de representação chega ao clímax, segundo Novaro. Surgiram organizações políticas orientadas para acolher interesses estáveis com bases territoriais, profissionais ou sociais definidas. Essa crise também levou o Estado a expandir o poder dos órgãos administrativos em detrimento dos "representativos". Há uma perda de relevância dos órgãos legislativos em favor do Executivo.

Novaro fala da desarticulação da sociedade que fica sem representação. No lugar de mecanismos eficazes de representação, "ressurgem identificações muito fortes com os líderes". "(...) o que afetou o cerne das formas representativas tradicionais foi algo mais: o enfraquecimento e a frag- 
mentação das identidades sociais (organizações de classe e grupos de interesse) e políticas (partidos) que até então participavam dos vínculos de representação". (idem, p.84)

Sem esse campo social estruturado, começa a compor-se o retrato de uma sociedade que carece de uma imagem de si como unidade, "uma sociedade sem vértice nem centro, um sistema sem porta-voz e sem representação interna" (MARRAMAO apud NOVARO, 1995, p.85) - uma "sociedade polimorfa”. (GALLI apud NOVARO, 1995, p.85) Segundo Novaro, quando há interesses difusos, a opinião do cidadão só é considerada enquanto pesquisa de opinião. São construídas então imagens e figuras capazes de mobilizar vontades, mesmo que transitoriamente. "Esta personalização da representação em líderes carismáticos foi vista como uma saída somente parcial da crise: eles se 'auto-apresentam' diante da sociedade, localizando-se em um vazio de imagens unificadas da própria sociedade, o qual não podem suprir de forma completa e duradoura. Permitem a tradução para o público de um conjunto disperso de vontades particulares, mas instauram um tipo de instabilidade perpétua no espaço público". (PÉREZ ANTÓN apud NOVARO, 1995, p.85)

Antonio Belinati, como líder carismático, acolhe no sentido mais afetivo do termo - as queixas das pessoas que o procuram, dá-lhes atenção e carinho, demonstrando preocupação com seus problemas. Com esse tratamento dado pelo próprio prefeito, os moradores mais carentes da cidade não sentem a necessidade de se organizar no bairro onde residem, na escola ou em qualquer outra entidade para discutir seus problemas e reivindicar soluções coletivas. Afinal muitos problemas são da coletividade. Para construir a cidadania, os moradores deveriam discutir entre si as dificuldades que enfrentam e exigir participação nas decisões políticas, o que significaria muitas vezes ter que "brigar" com o poder público. Ora, quem é o poder público? Nesse caso, é Antonio Belinati, tão gentil, cordial e carinhoso com a população. Abre as portas do gabinete e recebe pessoalmente cada um que chega até ele. Por que se indispor? Essa atenção no nível pessoal provoca um vácuo no espaço público.

Na campanha de 1996, Belinati usou um recurso bastante moderno, a pesquisa qualitativa, para detectar e, depois, "representar" a vontade popular. Segundo o prefeito - em entrevista à autora - , essa pesquisa permite saber como o eleitor está avaliando o candidato no dia-a-dia, quais as propostas que estão ou não agradando e qual é a proposta do adversário que está ou não agradando. "Então, acho que foi o que salvou nossa vitória na última eleição, porque em determinado momento nosso adversário estava plantando a imagem do prefeito do emprego e eu vi que a nossa campanha estava encruada. Aí contratamos um pessoal de Belo Horizonte, São Paulo e Porto Alegre e eles fizeram a pesquisa qualitativa e a gente detectou que um ponto extremamente importante era emprego. Aí eu fui para a TV toda noite e 'emprego, emprego, emprego, emprego'. Nós tiramos a chupeta da boca do adversário, passamos a bandeira do emprego para o lado de cá. Eu não sei se ele tinha uma pesquisa qualitativa. (...)". (BELINATI, 1999)

Belinati não precisa de programa de partido. Como ele próprio admite, adotou outras propostas no curso da campanha eleitoral de 1996 para agradar os eleitores. Passou a prometer no programa eleitoral da televisão aquilo que o eleitor queria ouvir: emprego, conforme havia apontado a pesquisa qualitativa. Belinati assume, portanto, que o tema do discurso pode variar de acordo com o que o eleitor quer em determinado momento. Essa atitude demonstra a completa falta de compromisso com o programa e a ideologia o partido. "A interferência do vínculo pessoal 'desideologiza' (camufla a ideologia), despolitiza um grupo de relações sociais que são, antes de tudo, políticas". (LENARDÃO, 1996, p.68)

Na campanha de 1976, Belinati também prometeu o que imaginava ir ao encontro dos anseios da população mais carente. "(...) no meu primeiro mandato lancei duas idéias malucas. Alguns achavam que era demagogia, que era loucura. Não havia nenhum posto de saúde na prefeitura. Eu disse: 'eleito, vou construir quatro postos de saúde pela prefeitura'. Aí a oposição disse que eu estava louco, que posto de saúde não era coisa de prefeitura e me 'batiam' no rádio, na TV, no horário eleitoral, no palanque. Eu me elegi e disse: 'bom, agora quem prometeu os postos de saúde foi o Antonio Belinati. Agora estou eleito'. E Deus permitiu o primeiro, o segundo, o quarto, o décimo [posto de saúde]. Até perdi a conta. Londrina tinha 1.173 moradias populares feitas por todos os prefeitos juntos. Lancei uma idéia aparentemente suicida: 'eleito prefeito, no meu mandato, construiremos 5 mil casas populares'. Aquilo causou um rolo nos adversários. Deus de novo permitiu e fizemos 5 mil, 8 mil, 12 mil, 20 mil de tal maneira que, hoje, das 32 mil casas populares que existem em Londrina feitas pela $\mathrm{COHAB}$, 27.431 foram construídas nas minhas gestões como prefeito. (...)". (BELINATI, 1999)

Assim como Getúlio Vargas instituiu a legislação trabalhista como um presente para os trabalhadores (que na verdade lutaram décadas por essa conquista), Belinati constrói casas populares - o déficit habitacional é uma realidade - como se fosse uma dádiva. Mas não propõe nenhum debate com a população para saber qual a melhor localidade, o melhor tipo de terreno para essas moradias; não define uma política de ocupação dos vazios urbanos em regiões que já contam com infra-estrutura. Ele promete as casas e as constrói. Age como um "pai" que provê a necessidade do filho porque sempre sabe o que é melhor para ele.

Belinati escolhe bem as palavras que usa. Na mesma entrevista, ele conta que parou de usar o termo pobre por sentir que tinha conotação pejorativa: “(...) O discurso para o pobre eu mudei a posição, porque o próprio pobre entende que é pejorativo você chamá-lo de pobre. Ele pode até saber que é pobre, mas, às vezes, até no boteco, para um agredir o outro, diz: 'ih, você é um pé de chinelo, você é um pobre'. Então procuro o máximo trocar essa palavra pobre por baixa renda, aposentado, desempregado, uma pessoa carente, porque a expressão 'pobre' está sendo colocada hoje de maneira meio agressiva. (...)". (idem)

$\mathrm{Na}$ entrevista, o prefeito não responde claramente a essa pergunta. Numa outra resposta, ele afirma: "grande parte dos que procuraram me batizar como o candidato dos pobres foi mais pelo lado pejorativo. Em Londrina, os pobres e os ricos votam para mim. Os pobres, na sua grande maioria. Tenho uma dificuldade exatamente na classe média, que pensa: 'ah, ele é o candidato dos pobres, não vou votar nele"'”. 
(idem) Ele diz ainda que muitos empresários já lhe disseram que parasse de fazer obras para os pobres porque estaria enchendo a cidade de pobres.

Antonio Belinati não tem efetivamente a preocupação de posicionar-se ao lado dos pobres em contradição aos ricos. Para ele, essa desigualdade sempre vai existir e não há como romper com a miséria. "Desde o tempo em que José teve que libertar o povo do Egito, sempre houve miséria. Seria uma utopia um político dizer que vai acabar com a miséria. Mas acho que se pode dar uma grande contribuição no sentido de diminuir o efeito dessa dor. E como se dá o remédio para diminuir essa dor? É a escola, o posto de saúde, o treinamento da mão-de-obra. Esse é o grande problema da humanidade. (...) Cabe a nós, prefeitos, governadores, empresários, fazer o melhor. (...) Com isso, você vai criando condições sociais num nível mais aceitável. Não tenho nenhuma ilusão em dizer que vou ser o prefeito que vai acabar totalmente com a miséria de Londrina (...)". (idem)

Belinati é um político conservador. Para ele, aceitar as diferenças sociais é algo quase natural. Seu grande mérito, segundo ele próprio, é o grande empenho para tornar menos sofrível a vida dessa população de baixa renda. Ele admite que pobres sempre existirão, e a única ação possível é a dos dirigentes políticos, que têm a responsabilidade de minimizar a miséria. Como ele mesmo disse na entrevista à autora, o que o povo mais quer é um "afago". Com o carisma que possui, vai mantendo-se no poder e distribuindo abraços e carinhos para os eleitores. Desmobilizada, a população mais carente sente-se confortada com o "pai-prefeito".

\section{CONSIDERAÇÕES FINAIS}

Como qualquer líder populista, Antonio Belinati mantém uma relação marcada pela pessoalidade com os eleitores. O político afirma que não acredita que isso ajude a despolitizar e desmobilizar a sociedade. "Pelo contrário, você dá mais liberdade. Já aconteceu de, até de madrugada, gente ligar para mim pedindo alguma coisa. É interessante que determinados prefeitos são chamados de doutores. As pessoas me chamam de Belinati. Acho até gostoso. Essa intimidade deixa as pessoas mais à vontade para reivindicar. $O$ que todos nós queremos, muito mais do que a solução do problema, é uma coisa que se chama afago. Não adianta uma pessoa me pedir dinheiro e eu dar 5 reais e dar um sermão. Ela vai pegar aquilo machucado. E pode ocorrer de você não ter dinheiro e dar uma palavra. Grande parte é isso que o povo quer. Esse é o cuidado que o político deve tomar. (...)". (idem)

Na ótica do prefeito, ninguém quer inverter a pirâmide social, marcada por alta concentração de renda em mãos de poucos, nem mudanças sociais efetivas. $O$ fato de os eleitores terem fácil acesso ao prefeito é sinal — na opinião dele - de que as reivindicações são feitas. Para avaliar as consequiências dessa política personalista em Londrina, seria necessário pesquisar a atuação dos movimentos sociais durante as administrações Belinati, observando-se se há cooptação de lideranças comunitárias e aniquilação dos adversários ou de quem tenta contrapor-se à política municipal.
Belinati atinge as pessoas mais pobres com a linguagem simples, de quem já vivenciou a miséria. “(...) quando eu vou à favela, eu estou falando com o favelado, eu conheço o dia-a-dia deles. (...) Essa identificação começa até com minha própria origem. (...) São muitas experiências de vida. Mas eu não uso isso em discurso. Você nunca me viu ficar retratando minha infância e dizendo: 'olhe, vote em mim'. (...) Por essa vivência é que acho que a gente conversa com a costureira, com a doméstica, com o motorista, com o aposentado, com a viúva, porque lá pra trás eu espelho problemas que a gente já viveu na própria casa. Então não se pode maquiar um líder político. Eu nunca tive um instrutor de política (...)". (idem)

Para Belinati, uma de suas principais virtudes como político é "não mudar o discurso". "É você conviver com gente de expressão e também com gente da camada mais humilde; é você jamais esquecer a sua origem. (...) O rico não precisa de prefeito (...). Quem precisa é essa camada carente, é o aposentado, o assalariado, essa população para quem a gente precisa trabalhar e muito. (...)". (idem)

Para Antonio Belinati, o seu papel enquanto político é manter uma relação de cordialidade com a população mais pobre e ser o escolhido para administrar os problemas da cidade. Ele não precisa seguir programa partidário, nem discutir com conselhos e entidades comunitárias. Quando está em contato com os mais carentes, detecta os problemas e necessidades e já propõe a solução que sabe ser a melhor. Constrói casas populares, postos de saúde, creches, hospitais - mas jamais submete à discussão popular qualquer um desses projetos, embora procure dar a aparência de que a decisão vem de "baixo" para "cima".

Com uma política personalista, os eleitores nunca terão maturidade nem condição de discutir os problemas, organizar-se e fazer uma revolução que garanta igualdade social. É preciso um líder que pense e aja por eles. Para Belinati, não existe conflito de classes, nem na hora da eleição. "(...) o povo não vota no político porque ele é rico ou mais pobre. A minha mãe saía pedindo votos para as amigas e, de vez em quando, ela encontrava uma amiga e pedia: 'vota no meu filho'. E a amiga dizia: 'não, não vou votar porque ele é pobre. O que ele vai poder fazer por mim?' Não adianta fazer o discurso 'eu sou rico' ou 'eu sou pobre', não é isso o que o povo está em busca”. (idem)

Ao mesmo tempo em que tem uma prática despolitizadora e que se orgulha de nunca ter dependido de partido para se eleger, na entrevista concedida à autora do trabalho revela uma contradição: "Eu espero que chegue o dia em que os partidos possam trabalhar mais em cima dos seus programas, de tal maneira que o partido, em vez de ser uma porta que se abre, faltando dois, três meses para a eleição, faça curso, treinamento, que faça debate dos programas. (...) Mas infelizmente os partidos aparecem com grande destaque no momento pré-eleitoral, um muda do partido, sai daqui vai pra lá. (...) Acho que o ideal é a gente ter partidos fortes (...)". (idem)

Esse discurso, no entanto, não encontra eco na prática de Belinati. Ele sustenta a imagem de benfeitor, defensor dos pobres, que não precisa de ninguém nem de partido que lhe diga como prosseguir. Com seu peculiar carisma, age em 
pleno final do século com o mesmo objetivo do início da carreira política, há trinta anos. O resultado alcançado nesse período só comprova que está no caminho certo. Se, quando assumiu a prefeitura pela primeira vez, aos 33 anos de idade, era movido pela intuição, hoje conta com a pesquisa qualitativa.

\section{REFERÊNCIAS BIBLIOGRÁFICAS}

ADUM, Hamil. "Campanha eleitoral. Talvez seja melhor candidato rico". Folha de Londrina. Londrina, 11 nov.1976, cad.2, p.2.

AS DECLARAÇÕES de Belinati aos maçons. Folha de Londrina. Londrina, 11 nov.1972, p.3.

AS METAS de Belinati. Folha de Londrina. Londrina, 18 nov.1988, p.1.

AVELINO FILHO, George. "Clientelismo e política no Brasil: revisitando velhos problemas. Novos Estudos Cebrap, n.38, p.225-240, mar. 1994.

BELINATI ACREDITA que já venceu. Folha de Londrina. Londrina, 16 nov.1988, p.4.

BELINATI, Antonio C. "Belinati: a política e os pobres". Londrina, 1999. Entrevista concedida a Carina Paccola.

BELINATI É O PREFEITO?. Folha de Londrina. Londrina, 16 nov. 1976 , p.2.

BELINATI LANÇA folheto "Você Decide". Folha de Londrina. Londrina, 21 ago.1996, p.4.

BELINATI: QUE RICHA cuide de nossa gente. Folha de Londrina. Londrina, 18 nov. 1972 , p.1.

BELINATI VENCE por apenas 838 votos. Folha de Londrina. Londrina, 17 nov.1988, p.1

BERNARDO É O MAIS POBRE dos candidatos - bens do candidato petista somam R\$ 128 mil. Belinati é o mais rico, com patrimônio de r\$ 490 mil. Folha de Londrina. Londrina, 25 ago.1996, p.5.

CANDIDATOS DEBATEM propostas para zona sul. Folha de Londrina. Londrina, 3 ago.1996, p.4

CINCO ELEITORES muito especiais. Folha de Londrina. Londrina, 16 nov.1976, p.2.

COHN, Gabriel. Sociologia da comunicação. Sāo Paulo: Pioneira, 1973.

CONJUNTOS COMEMORARAM a vitória de Belinati. Folha de Londrina. Londrina, 18 nov.1988, p.3.

DEUS E O POVO ME ESCOLHERAM para administrar Londrina. Folha de Londrina. Londrina, 17 nov.1976, p.3.

E BELINATI DIZ que é obra do próprio MDB. Folha de Londrina. Londrina, 9 nov.1988, p.3.

FEARING, Franklin. “A comunicação humana”. In: COHN, Gabriel. (org.). Comunicação e indústria cultural. São Paulo: Companhia Editora Nacional, 1975. p.56-82.

FERREIRA, Pedro Roberto. "Política, marketing e neoliberalismo". Revista Mediaçães, v.1, n.1, p.14-17, jan./jun. 1996.

FREYRE, Gilberto. Interpretação do Brasil. Rio de Janeiro: José Olympio Editora, 1947

HABERMAS, Jürgen. “Comunicação, opinião pública e poder". In: COHN, Gabriel. (org.). Comunicação e indústria cultural. São Paulo: Companhia Editora Nacional, 1975. p.187-200.

HOLANDA, Sérgio Buarque de. "Nossa revolução". In: Raízes do Brasil. São Paulo: Companhia das Letras, 1995. p.171-188.

HOLANDA, Sérgio Buarque de. "O poder pessoal". In: História geral da civilização brasileira. São Paulo: Difel, 1972. p.187-201.

IANNI, Otávio. O colapso do populismo no Brasil. Rio de Janeiro: Civilização Brasileira, 1971.

LENARDÃO, Elsio. O 'vereador do bairro'. Londrina, 1996. Monografia
(Especialização em Sociologia e Sociologia da Educação) - Universidade Estadual de Londrina.

LOMBA, Luis. "Bernardo apresentou as propostas mais concretas". Folha de Londrina. Londrina, 17 jul.1996a, p.4.

"Belinati cai mas permanece na frente". Folha de Londrina. Londrina, 4 ago.1996b, p.4.

"Belinati é favorito no segundo turno". Folha de Londrina. Londrina, 16 ago. $1996 \mathrm{c}$, p. 4 .

LONDRINA e Maringá, de novo MDB. Folha de Londrina. Londrina, 17 nov.1972, p.1.

MARTINS, José de Souza. O poder do atraso. São Paulo: Hucitec, 1994

MDB SAI na frente. Folha de Londrina. Londrina, 16 nov.1976, p.1.

NOVARO, Marcos. "O debate contemporâneo sobre a representação política. Novos Estudos Cebrap, n.42, p.77-90, jul.1995.

O FENÔMENO Belinati chega à Prefeitura. Folha de Londrina. Londrina, 17 nov. 1976, p.1.

O POVO JÁ DECIDIU: Belinati prefeito!. Folha de Londrina. Londrina, 15 nov. 1972 , p. 3 .

OGAMA, Walter. "Frases de efeito invadem programas". Folha de Londrina. Londrina, 7 ago.1996a, p.5.

"Depois do debate, a caça ao voto durante 1 almoço e 2 churrascadas". Folha de Londrina. Londrina, 21 ago.1996b, p.4.

"Segundo turno divide Belinati e Hauly". Folha de Londrina. Londrina, 31 ago. $1996 \mathrm{c}$, p.4.

OLHA O NÍVEL. Folha de Londrina. Londrina, 10 nov.1988, p.30.

PACCOLA, Carina. "Hauly promete vencer no primeiro turno". Folha de Londrina. Londrina, 16 ago.1996a, p.4.

"Planejamento e tarifas preocupam empresários". Folha de Londrina. Londrina, 25 ago.1996b, p.4

“"Urna eletrônica nos tirou a vitória', diz Belinati”. Folha de Londrina, Londrina, 5 out. $1996 \mathrm{c}$, p.4.

PRIMEIRO VOTO foi de Stamm. Folha de Londrina. Londrina, 17 nov.1972, p.12.

STONE, Philip J. "A análise de conteúdo da mensagem". In: COHN, Gabriel. (org.). Comunicação e indústria cultural. São Paulo: Companhia Editora Nacional, 1975. p.315-332.

TAVARES PERDE VOTOS dos eleitores analfabetos. Folha de Londrina. Londrina, 17 ago.1996, p.4.

THIOLLENT, M. Opinião pública e debates políticos: subsídios metodológicos. São Paulo: Polis, 1986.

WEFFORT, Francisco. O populismo na política brasileira. Rio de Janeiro: Paz e Terra, 1980. 